\title{
Additions to continental gastropods from the Upper Cretaceous and Paleocene of NE Mexico
}

Francisco J. Vega

Instituto de Geología, Universidad Nacional Autónoma de México, CDMX 04510, Mexico.

\section{Edna Naranjo-García}

naranjo@unam.mx

Instituto de Biología, Departamento de Zoología, Universidad Nacional Autónoma de México, Ciudad Universitaria, Apartado Postal 70-153, CDMX 04510, Mexico.

\section{Martha Garolina Aguillón}

Daniel Posada-Martínez

Secretaría de Educación Pública de Coahuila-Museo del Desierto, Prolongación Pérez Treviño 3745 Centro, Saltillo, Coahuila 25015, Mexico.

BOL. SOC. GEOL. MEX. 2019

VOL. 71 NO. 1

P. $169-191$

http://dx.doi.org/10.18268/BSGM2019v7lnla9

\section{ABSTRACT}

Additions are offered to the diverse estuarine, freshwater and terrestrial gastropod fauna of the Upper Cretaceous (Campanian) and Paleocene lithostratigraphic units of the Difunta Group, NE México (Coahuila and Nuevo León). Nineteen species of continental gastropods (five of them new) are reported and illustrated from the upper Campanian Cerro del Pueblo Formation (Las Águilas/Porvenir de Jalpa locality) and the Paleocene Las Encinas Formation (La Leona locality), northern Parras Basin, Difunta Group, Coahuila. The first record of pulmonate gastropods from the Difunta Group is based on several specimens of different species. This is the third contribution dealing with these continental gastropods from the study region and a revised list of reported species is presented. Although we follow the most recent classification of continental gastropods, we also base the identification on paleontological systematics, knowing that some important diagnostic features were not preserved. Thus, we do not intend to propose paleobiogeographic or evolutionary inferences. Our main goal is to present the paleodiversity known from the study area, in hope that these data would be useful for more detailed studies in the near future.

Keywords: Continental Mollusca, Gastropoda, Upper Gretaceous, Paleocene, Goahuila, Mexico.

\section{RESUMEN}

Se ofrecen adiciones a la diversa fauna de gastrópodos estuarinos, dulceacuícolas y terrestres de las unidades litoestratigráficas del Cretácico Superior (Campaniano) y Paleoceno del Grupo Difunta, NE de México (Coahuila y Nuevo León). Diecinueve especies de gastrópodos continentales (cinco de ellas nuevas) son reportadas e ilustradas para la Formación Cerro del Pueblo del Campaniano superior (localidad Las Águilas/Porvenir de Jalpa) y la Formación Las Encinas, del Paleoceno (localidad La Leona), porción norte de la Cuenca de Parras, Grupo Difunta, Coahuila. El primer registro de gasterópodos pulmonados para el Grupo Difunta, se basa en varios ejemplares de diferentes especies. Esta es la tercera contribución que trata sobre caracoles continentales de la región y se presenta una lista revisada de especies. Aunque seguimos la más reciente clasificación de gasterópodos continentales, también basamos la identificación en sistemática paleontológica, concientes de que algunas características diagnósticas importantes no fueron preservadas. Por lo tanto, no intentamos proponer inferencias evolutivas o paleobiogeográficas. Nuestro propósito principal es presentar la paleodiversidad conocida para el área de estudio, en espera de que pueda ser de utilidad para estudios más profundos a futuro.

Palabras clave: Mollusca continentales, Gastropoda, Cretácico Superior, Paleoceno, Coahuila, México. 


\section{Introduction}

The fossil record of the Parras and La Popa basins (Difunta Group) includes a diversity of plants, invertebrates and vertebrates, distributed in diverse facies of a deltaic system that prevailed in northeastern Mexico from late Campanian to Paleocene (e.g., McBride et al., 1974; Wolleben, 1977; Vega and Perrilliat, 1989; Lawton et al., 2009). McBride et al. (1974) subdivided the Difunta Group into two sedimentary basins, the Parras and La Popa basins. Vega and Perrilliat (1992) first report continental gastropods from the Paleogene deposits of the La Popa Basin (Nuevo León). Later, Perrilliat et al. (2008) reported eleven species of freshwater gastropods from three localities of the Cerro del Pueblo Formation (Parras Basin, Coahuila). The abundance and diversity of continental gastropods, as found in lithostratigraphic units of the Difunta Group is unique in Mexico.

Although the systematics of continental gastropods are mostly based on soft-body features and molecular data, it is important to know the occurrence of these organisms, whose shell morphology resembles living species distributed around the world. The data could also be helpful for detailed paleogeographic reconstructions of the late Campanian and middle Paleocene sea shore in NE Mexico. This is because the habitats of these gastropods correspond to ponds, marshes, and swamps found near the ancient coast of NE Mexico. Continental molluscs represent the most abundant and diverse fossils of the Difunta Group, being one of the most important for facies interpretation, since nearly all of these gastropods and bivalves are found with little or no transport from their original habitats.

Salt tectonics played an important role in facies distribution and occurrence, mainly at La Popa Basin (Giles and Lawton, 1999, 2002; Lawton et al., 2001, 2009). This halokinetic control was important, especially during Paleocene times, in the formation of small, closed shallow basins. In these zones, organic matter accumulated in estuarine to freshwater environments, and aquatic continental gastropod populations developed.

On the other hand, late Campanian sequences of the Parras Basin also had significant changes in facies, but with deposition in low-gradient lower coastal plain and shallow marine environments, influenced by high-frequency changes in relative sea level, and coastal storm events (Eberth et al., 2004). This difference may explain the complete absence of terrestrial pulmonate snails in the Paleocene units of La Popa Basin. Figure 1.1 and 1.2 illustrate inferred paleogeography for NE Mexico during Late Cretaceous and Paleocene.

\section{Stratigraphy and localities}

\subsection{LATE GAMPANIAN, GERRO DEL PUEBLO FORMATION}

The Cerro del Pueblo Formation is the oldest (late Campanian) lithostratigraphic unit of the Parras Basin (McBride et al., 1974, Eberth et al., 2004) and includes shallow sedimentary environments, represented by delta plains, lagoons, and marshes, located in the ancient northeast coast of Mexico (Figure 1.1). Relatively similar environments were found during the Paleocene in this region (Figure 1.2). A diversity of marine, freshwater, and terrestrial animals has been described from several localities in NE Mexico (Figure 1.3). Perrilliat et al. (2008) reported important fossiliferous outcrops of the Cerro del Pueblo Formation. Its lithology and fossiliferous content is similar to the locality here described as Las Águilas/Porvenir de Jalpa, General Cepeda, Coahuila $\left(25^{\circ} 31^{\prime} 03^{\prime \prime} \mathrm{N}\right.$, $101^{\circ} 40^{\prime} 30^{\prime \prime} \mathrm{W}$ ) (Figure 1.4), also from the Cerro del Pueblo Formation. In the latter, light-brown, fine-grained sandstone beds yield hematized gastropods, bivalves, tortoise bones, crocodile teeth, coprolites, wood fragments, and fruits, preserved under anoxic, stagnant freshwater deposits. Estuarine, non-hematized gastropods are also found a few meters above level with hematized remains. The freshwater strata are relatively thin 


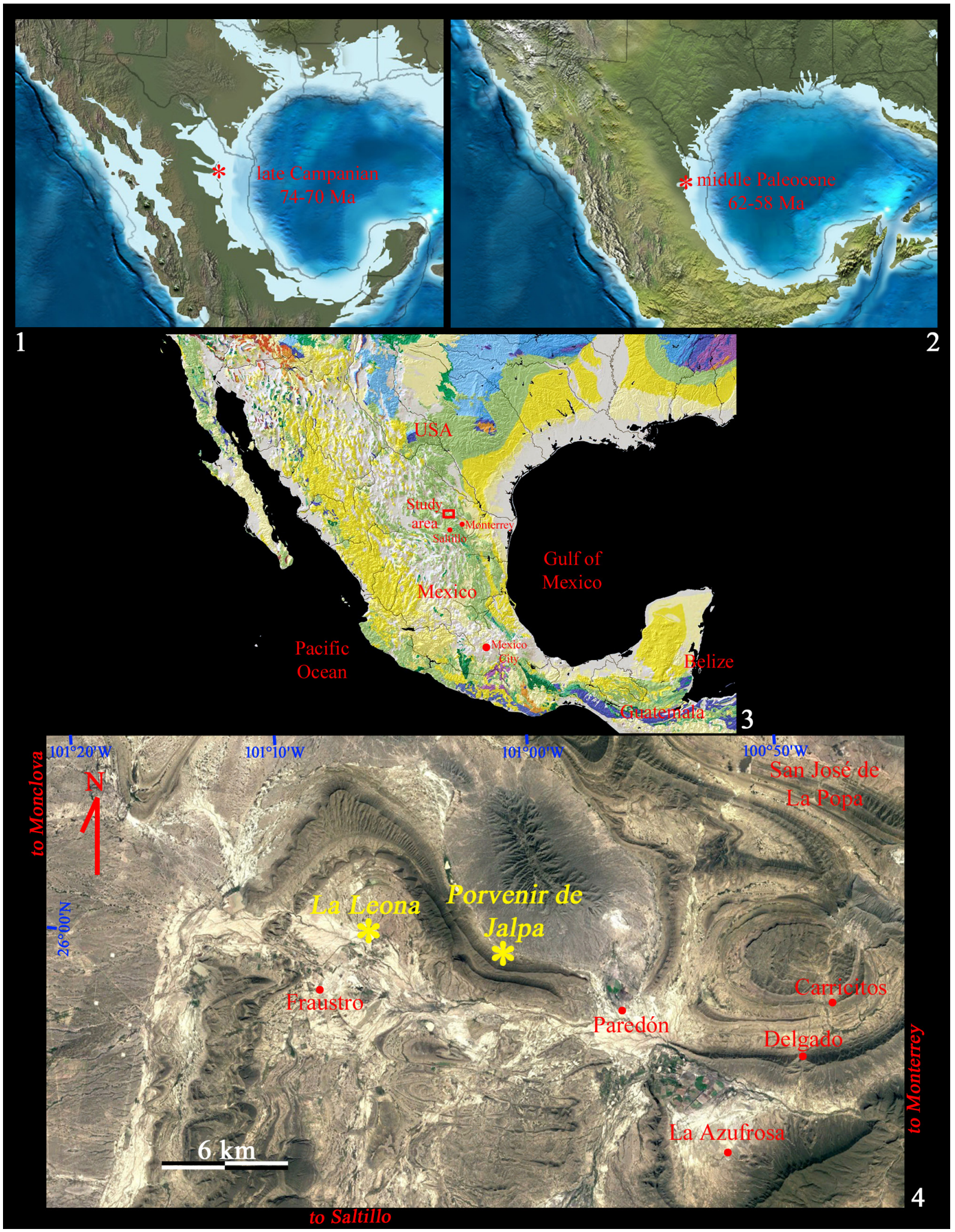

Figure 1 1, Late Cretaceous paleogeographic map, with approximate position of Las Águilas/Porvenir de Jalpa locality. 2, Paleocene paleogeographic map, with approximate position of La Leona locality. 3, Geologic map with position of study area in NE Mexico. 4, Map of study localities in Coahuila, NE Mexico. Paleogeographic maps courtesy of Ron Blakeley (modified). Figure 1.3 modified from Barton et al. (2003). Figure 1.4 from Google Earth. 
and interbedded in cyclic sequences with shallow marine sediments that include the ostreoid Flemingostrea subspatulata Forbes, 1845 and the ammonite Sphenodiscus sp.

Here we report seventeen species of continental gastropods for the upper Campanian Cerro del Pueblo Formation. Five of them are new and three species were previously reported by Perrilliat et al., 2008 for the Cerro del Pueblo Formation, but from different localities (Figure 2). Pulmonate gastropods are here reported for the first time for the Difunta Group. A total of 30 continental gastropods are now known from the Cerro del Pueblo Formation (Figure 3), and a significant number of bivalves are to be reported in future studies.

\subsection{PALEOGENE, LAS ENGINAS FORMATION}

Four species of freshwater gastropods were reported by Perrilliat et al. (2008) from red beds (delta plain) of the Las Encinas Formation (Parras Basin). The Paleocene Adjuntas, Viento and Carroza formations in La Popa Basin also contain

\begin{tabular}{|c|c|c|c|c|c|}
\hline & $\begin{array}{l}\frac{8}{0} \\
\frac{0}{0} \\
0\end{array}$ & $\begin{array}{l}\text { 웡 } \\
\text { 유 }\end{array}$ & Stage & $\begin{array}{l}\text { Parras } \\
\text { Basin }\end{array}$ & $\begin{array}{c}\text { La Popa } \\
\text { Basin }\end{array}$ \\
\hline \multirow{5}{*}{ 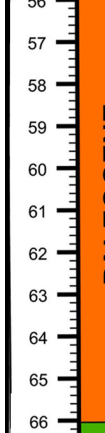 } & \multirow{5}{*}{$\begin{array}{l}\text { 岁 } \\
\text { 岁 } \\
\text { 号 } \\
\text { 崖 }\end{array}$} & \multirow{5}{*}{ 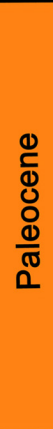 } & \multirow{3}{*}{ Thanetian } & & CARROZA * \\
\hline & & & & \multirow{2}{*}{ RANCHO NUEVO } & VIENTO \\
\hline & & & & & ADJUNTAS * \\
\hline & & & Selandian & $\begin{array}{l}\infty \\
\mathbb{Z}\end{array}$ & $\Omega$ \\
\hline & & & Danian & $\begin{array}{l}J \\
z \\
z \\
1 \\
\infty \\
4 \\
J\end{array}$ & $\begin{array}{l}0 \\
د \\
\lrcorner \\
\beth \\
\simeq\end{array}$ \\
\hline & \multirow{5}{*}{ 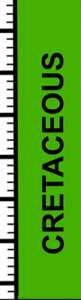 } & \multirow{5}{*}{ 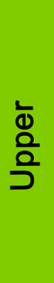 } & Upper & CERRO GRANDE & $\approx$ \\
\hline & & & $\begin{array}{l}\text { Maas- } \\
\text { trichtian }\end{array}$ & LAS IMÁGENES & 0 \\
\hline 71 寻 & & & Lower & CAÑÓN DEL TULE & a \\
\hline 27 & & & & \begin{tabular}{|l|} 
CERRO HUERTA \\
\end{tabular} & \\
\hline & & & Campanian & $\begin{array}{l}\text { CERRO DEL PUEBLO } \\
\text { PARRAS SHALE } \\
\end{array}$ & \begin{tabular}{|l|} 
MUERTO \\
PARRAS SHALE
\end{tabular} \\
\hline
\end{tabular}

Figure 2 Distribution of continental gastropods in Campanian and Paleocene lithostratigraphic units of the Difunta Group, Parras and La Popa basins.. continental gastropods. These specimens were found in delta-plain deposits, with some species in common with those from the Paleocene of Las Encinas Formation (Figure 2). Two species of continental gastropods are here reported from fluvial deposits of the Paleocene Las Encinas Formation at La Leona locality, Ramos Arizpe, Coahuila, $\left(25^{\circ} 58^{\prime} 47^{\prime \prime} \mathrm{N}, 101^{\circ} 06^{\prime} 23^{\prime \prime} \mathrm{W}\right)$ (Figure 1.4). A total of 12 Paleocene continental gastropod species are now known from the Paleocene Las Encinas, Adjuntas, and Carroza formations (Figure 3).

Figure 2 illustrates the Upper Cretaceous and Paleocene lithostratigraphic units of the Difunta Group (Parras and La Popa basins), indicating those that yield continental gastropods, for a total of 42 species now known from the Campanian-Paleocene deposits of the Difunta Group (Figure 3). Acronym used: CPG which stands for the Colección de Paleontología, Museo del Desierto, Saltillo, Coahuila.

The order of families is based on Bouchet et al. (2017).

\section{Systematic paleontology}

Class Gastropoda Cuvier, 1797

Subclass Caenogastropoda Cox, 1959

Order Sorbeoconcha Ponder and Lindberg, 1997

Superfamily Cerithioidea Fleming, 1822

Family Hemisinidae Fischer and Crosse, 1891

Genus Pyrgulifera Meek, 1877

Pyrgulifera humerosa (Meek, 1860)

Figures $4.1-4.3$

Description. Elongate shell, with concave shoulder and transversal ribs that finish as tubercles. Fine spiral lines and fine growth lines over the ribs, which give the shell reticulate appearance. Suture well marked. Apex not well preserved and aperture absent.

Material examined. Four specimens, CPC1034, height $=26.3 \mathrm{~mm}$, width $=17.1 \mathrm{~mm}$, whorls $=6$; CPC-1035, height $=21.7 \mathrm{~mm}$, width $=12.6 \mathrm{~mm}$, whorls $=5 ;$ CPC-1036, height $=18.7$ 
D i funta Grou p

\section{GASTROPOD SPECIES}

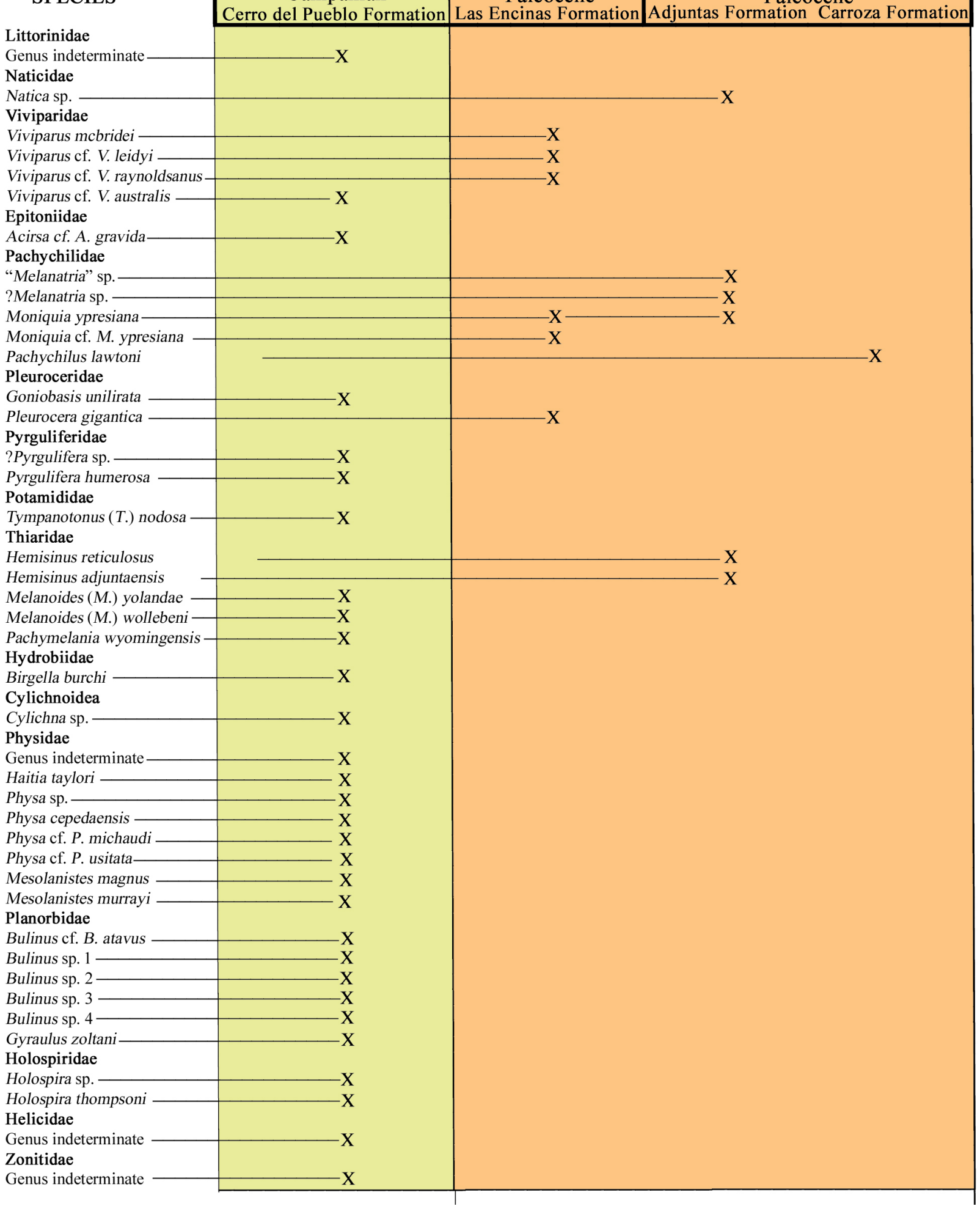


$\mathrm{mm}$, width $=14.4 \mathrm{~mm}$, whorls $=6$ remaining; CPC-1037, height $=19.6 \mathrm{~mm}$, width $=14.0 \mathrm{~mm}$, whorls $=4$ remaining.

Occurrence. Las Águilas/Porvenir de Jalpa, General Cepeda, Coahuila, Cerro del Pueblo Formation, upper Campanian. Wyoming, Bear River Formation, Eocene; Sulphur Creek, Utah, Upper Kanab.

Discussion. The specimens studied here have the characteristics seen in Pyrgulifera humerosa (Meek, 1860) from the Cenomanian Bear River Formation, Wyoming. Yen (1958) reached the conclusion that the genus became extinct in the Maastrichtian.

Pyrgulifera has been found in limestone and calcareous shales, together with fresh water genera, However, there is evidence that it was in associations of alternating fresh to brackish water, nonetheless of low salinity (estuary) (Yen, 1958). Pyrgulifera Meek, 1877 is a fossil mollusk inhabiting brackish and freshwater environments, although Bandel and Riedel (1994) suggested that the habitat for the genus was more of brackish water, with certain tolerance of fresh water. Its distribution was greatest during the Late Cretaceous and also during the late Cenomanian (Yen, 1958). Its distribution includes the Sulphur Creek, near Bear River, southwest Wyoming (Yen, 1958). In Europe, it has been found in southern France in lignite beds in the Rhone River basin. Yen (1958) considered Hantkenia munieri Repelin, 1902 from the upper Cenomanian Gardonian Formation of southeast France, a true Pyrgulifera. Various species of Pyrgulifera were described from the coal beds of the Gosau Formation close to Brandenberg, Austria. In addition, in western Hungary other set of species was described from the coal seams of the Ajka Formation (Yen, 1958). Stilwell (1997) recorded Pyrgulifera kahuitara Stilwell, 1997 from the Campanian?-Maastrichtian Kahuitara Tuff of Pitt Island,
New Zealand. To Stilwell (1997), Pyrgulifera distribution includes Genomanian to Danian fossiliferus beds of Europe, North America, Asia, India, New Caledonia, and Chatman Islands. However, differing from Yen (1958) who believed that Pyrgylifera was a brackish and freshwater inhabitant, Stilwell (1997), at least for Pyrgulifera kahuitara, considered it from a marine environment.

Family Pachychilidae Fischer and Crosse, 1892 Genus Moniquia Pacaud and Harzhauser, 2012 Moniquia ypresiana (Vega and Perrilliat, 1992) new combination

Figures 4.10, 4.11

Description. Shell medium-sized, turreted; protoconch unknown; teleoconch of four whorls, convex; sculpture of curved axials of moderate strength that extends from suture below almost to suture above; spiral sculpture of threads of subequal strength; aperture not preserved.

Material examined. Two specimens, CPC2145, height $=62.3 \mathrm{~mm}$, width $=19.2 \mathrm{~mm}$, whorls $=6$; CPC-2146, height $=9.2 \mathrm{~mm}$, width $=$ $6.2 \mathrm{~mm}$, whorls $=5$.

Occurrence. La Leona, Ramos Arizpe, Coahuila, Las Encinas Formation, Paleocene.

Discussion. Pacaud and Harzhauser (2012) made a review of Cretaceous and Paleogene species of relatively similar genera, including Melanatria Bowdich, 1822. Most of the morphological features used by these authors to erect the genus Moniquia are found in the numerous specimens of M. ypresiana, first reported from the Paleocene Adjuntas Formation of La Popa Basin, Difunta Group, Nuevo León (Vega and Perrilliat, 1992). Although an early Eocene age (Ypresian) age was originally interpreted for the Adjuntas Formation, more recent data suggest a middle Paleocene age for this lithostratigraphic unit (Lawton et al., 2009). 


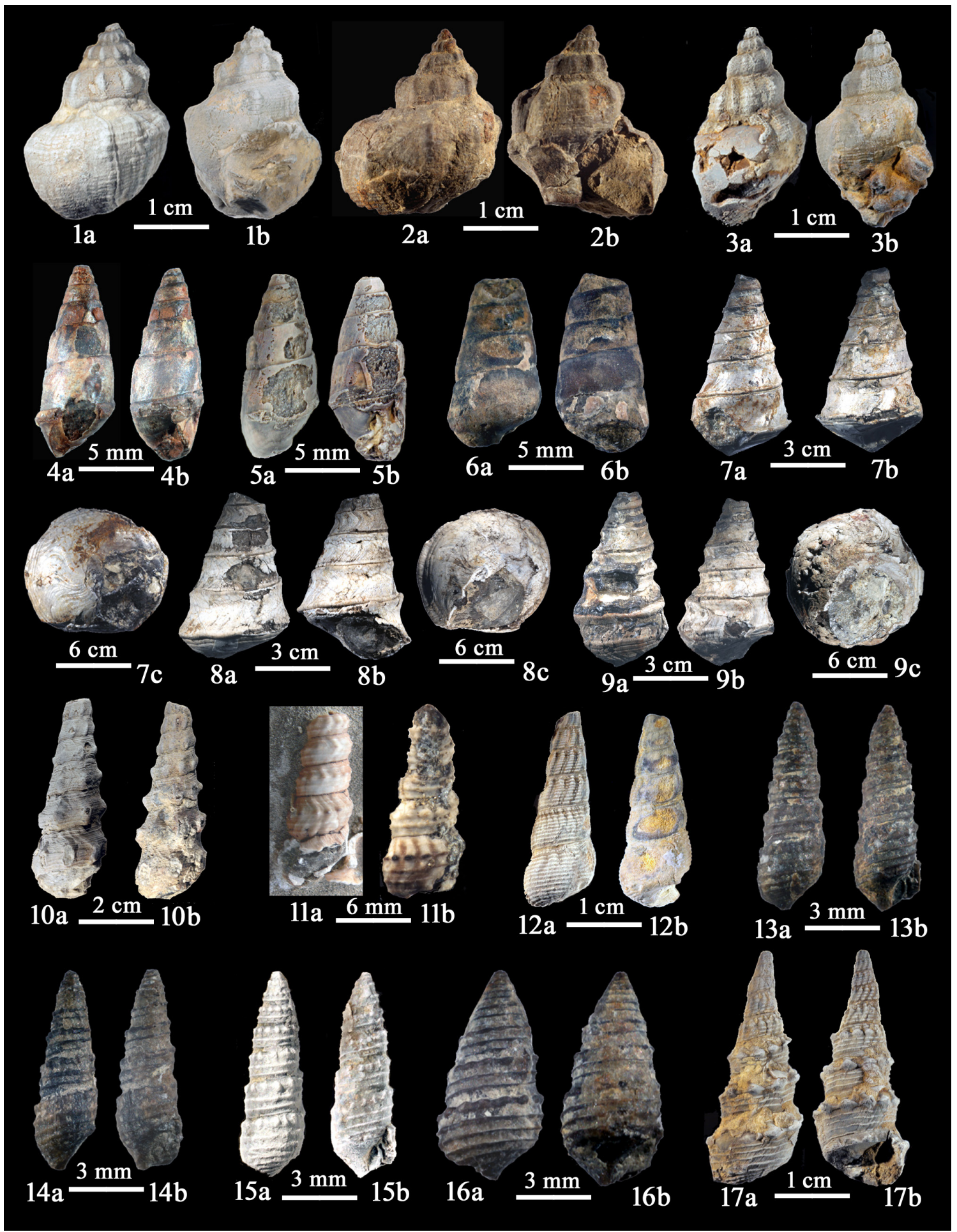

Figure 41 - 3, Pyrgulifera humerosa; 1a, 1,034, ad.; 1b, ap.; 2a, 1,035, ad.; 2b, ap.; 3a, 1036, ad.; 3b, ap. 4 - 6, Goniobasis unilirata NaranjoGarcía and Aguillón, n. sp.; 4a, ho. 1042, ad.; 4b, ap.; 5a, pa. 1,043, ad.; 5b, ap.; 6a, pa. 1,044, ad.; 6b, ap. 7 - 9, Pleurocera gigantica NaranjoGarcía and Aguillón, n. sp.; 7a, ho. 1047, ad.; 7b, ap.; 7c, po.; 8a, pa. 1048, ad.; 8b, ap.; 8c, po.; 9a, pa. 1,049, ad.; 9b, ap.; 9c, po. 10, 11, Moniquia ypresiana; 10a, 2145, ad.; 10b, ap.; 11 a, 2146, ad.; 11 b, ap. 12, Acirsa cf. A. gravida; 12a, 2160, ad.; 12b, ap. 13 - 15, Melanoides (Melanoides) yolandae; 13a, 1,038, ad.; 13b, ap.; 14a, 1,039, ad.; 14b, ap.; 15a, 1,040, ad.; 15b, ap. 16, M. (M.) wollebeni; 16a, XXXX, ad.; 16b, ap. 17, Pachymelania wyomingensis; 17a, 2147, ad.; 17b, ap. 1 - 6, 12 - 17, Coahuila, Cerro del Pueblo Formation, Campanian; 7 - 11 , Coahuila, Las Encinas Formation, Paleocene. $\mathrm{Ad}=$ adapertural, ap $=$ apertural, ho $=$ holotype, pa $=$ paratype, po $=$ posterior . 
Specimens are abundant in green mudstone of delta plain facies in the Adjuntas and Las Encinas formations.

Family Pleuroceridae Fischer, 1885

Genus Goniobasis Lea, 1862

Goniobasis unilirata Naranjo-García and Aguillón, new species

Figures $4.4-4.6$

Diagnosis. Medium sized elongate conic shell, 5 to 7 whorls; smooth surface, with carinate periphery, aperture elongated, bent columella.

Description. Medium sized shell, elongate conic, whorls flattened, well-marked suture, 5 to 7 whorls. Smooth surface, with carinate periphery over the body whorl, apex unknown, aperture elongated, bent columella to the outside with a lamella over it.

Material examined. Five specimens, holotype CPC-1042, height $=14.9 \mathrm{~mm}$, width $=6.0 \mathrm{~mm}$, whorls $=6$; paratype CPG-1043, height $=13.5$ $\mathrm{mm}$, width $=5.9 \mathrm{~mm}$, whorls $=5$; paratype CPC1044 , height $=10.6 \mathrm{~mm}$, width $=4.8 \mathrm{~mm}$, whorls unmeasurable; paratype CPC-1045, height $=$ $9.9 \mathrm{~mm}$, width $=5.2 \mathrm{~mm}$, whorls $=5$ remaining; paratype CPC-1046, height $=9.6 \mathrm{~mm}$, width $=$ $4.8 \mathrm{~mm}$, whorls $=7$.

Occurrence. Las Águilas/Porvenir de Jalpa, General Cepeda, Coahuila, Cerro del Pueblo Formation, upper Campanian.

Discussion. Goniobasis unilirata n. sp. resembles $G$. macilenta White, 1895 of the Bear River Formation of Wyoming and Utah, in the flattened whorls and smooth surface (Grabau and Shimer, 1909). However, G. macilenta has no carina over the body whorl, being taller and more slender than $G$. unilirata $\mathrm{n}$. sp. The family Pleuroceridae has an ample distribution. It is found in North and South America, Africa, and Asia. However, the family has had its maximum development in North America (Burch, 1989).
Etymology. The name "unilirata" is given due to the presence of a ridge over the shoulder of the body whorl of the specimens.

Genus Pleurocera Rafinesque, 1818

Pleurocera gigantica Naranjo-García and Aguillón, new species

Figures $4.7-4.9$

Diagnosis. Shell conic elongated, imperforated, over 10 whorls; whorls with well-marked wave shaped growth lines, with basal cord over the suture; suture strongly indented; base of body whorl with three to six spiral cords; periphery of shell angular at body whorl; parietal callus ample, extending to columellar base.

Description. Shell conic elongated, imperforated, all the specimens lack the apex. The species has over 10 whorls. Sculpture: whorls remaining with well-marked wave shaped growth lines (retracted in the middle: »). Whorls have a basal cord over the suture. Suture strongly indented, whorls round and swollen below the cord of previous whorl. Base of body whorl with three to six spiral cords (three in juvenile specimens and six in mature ones). One cord at the edge of the whorl, the most voluminous (prominent), and the other immediately below (less developed), then 4 spiral incised lines after the cords. At body whorl the periphery of shell is angular. Parietal callus ample, which extends to columellar base; rest of aperture unknown.

Material examined. Twelve specimens, see Table 1.

Occurrence. La Leona, Ramos Arizpe, Coahuila, Las Encinas Formation, Paleocene.

Discussion. Pleurocera gigantica n. sp. resembles P. unciale hastatum (Anthony, 1854) of the Recent, from North and South Fork of the Holston River, Sullivan County Tennessee (Burch, 1988) in the general outline of the shell; its body whorl is also angular, with two cords at the base close to the 
Table 1. Measurements of Pleurocera gigantica Naranjo-García and Aguillón new species, from the Paleocene Las Encinas Formation, Parras Basin.

\begin{tabular}{|c|c|c|c|c|}
\hline $\begin{array}{l}\text { Catalog } \\
\text { number }\end{array}$ & Туре & $\begin{array}{c}\text { Height } \\
\text { mm }\end{array}$ & $\begin{array}{l}\text { Width } \\
\text { mm }\end{array}$ & $\begin{array}{l}\text { Whorls } \\
\text { number }\end{array}$ \\
\hline CPC-1,047 & Holotype & 74.5 & 43 & 7 \\
\hline CPC- 1,048 & Paratype & 80.6 & 45 & 7 \\
\hline CPC-1,049 & Paratype & 74.7 & $\begin{array}{c}\sim 39.9 \\
\text { (incomplete aperture) }\end{array}$ & 7 \\
\hline CPC- 1,050 & Paratype & 61.8 & $\begin{array}{c}42.6 \\
\text { (incomplete aperture) }\end{array}$ & 5 \\
\hline CPC-1,051 & Paratype & 71 & 50.8 & 4 \\
\hline CPC- 1,052 & Paratype & 67 & 38.9 & 8 \\
\hline CPC- 1,053 & Paratype & 66.3 & 38.6 & 8 \\
\hline CPC-1,054 & Paratype & 80.8 & 43.2 & 8 \\
\hline CPC- 1,055 & Paratype & 61.5 & 43.5 & 5 \\
\hline CPC- 1,056 & Paratype & 95.2 & 47.3 & 5 \\
\hline CPC-1,057 & Paratype & 84.7 & 51.9 & \\
\hline CPC-1,058 & Paratype & 61.5 & $\begin{array}{l}\text { Sectioned specimen } \\
\text { in the middle }\end{array}$ & 4 \\
\hline
\end{tabular}

suture. Also, the new species reached over 100 $\mathrm{mm}$, while $P$. unciale hastatum has a height of 23.5 $\mathrm{mm}$; other differences are that $P$. gigantica $\mathrm{n}$. sp. has a deeper suture and the base of the body whorl has 4 spiral incised lines after the cords. It should be noted that the known Pleuroceridae of the Recent from the United States are small (about $22 \mathrm{~mm}$; Burch, 1989), and in South America can reach $50 \mathrm{~mm}$ (Simone, 2006). The specimens examined here are three to five times taller.

The family Pleuroceridae is distributed in North and South America, Africa and Asia; nonetheless, its maximum diversity is seen in North America (Burch, 1989). It is of interest to note that Mesozoic and Paleogene records were very different to the faunas seen in later times (Pliocene), Taylor (1985) alludes to a remarkable situation, pointing out that among other freshwater molluscan families the Pleuroceridae was of a massive size. Such is the case of the Pleurocera gigantica described herein. In the Recent, Goniobasis and Pleurocera have a large number of North American species (Thiele, 1931-1935).
Etymology. It is named because of the unusual big size for a Pleurocera species.

Family Thiaridae Gill, 1871

Genus Melanoides Oliver, 1804

Melanoides (Melanoides) yolandae Perrilliat, Vega, Espinosa and Naranjo-García, 2008

Figures $4.13-4.15$

Description. Shell small, slender, turreted; protoconch unknown; teleoconch of eight whorls; whorls profile straight; suture impressed; the first three whorls with two beaded spirals, subsequent whorls with three beaded spirals, the anterior whorl less prominent; last whorl with eight spirals, only the upper three remain beaded, the others becoming nearly smooth; axial sculpture not preserved; aperture ovate.

Material examined. Three specimens, CPG1038 , height $=10.3 \mathrm{~mm}$, width $=2.2 \mathrm{~mm}$, whorls $=6 ;$ CPC-1039, height $=9.8 \mathrm{~mm}$, width $=2.3$ $\mathrm{mm}$, whorls $=5$; CPC-1040, height $=10.7 \mathrm{~mm}$, width $=2.4 \mathrm{~mm}$, whorls $=6$.

Occurrence. Las Águilas/Porvenir de Jalpa, General Cepeda, Coahuila, Cerro del Pueblo Formation, upper Campanian.

Discussion. More than 200 specimens of this species were reported by Perrilliat et al. (2008) from outcrops of the upper Campanian Cerro del Pueblo Formation near Rincón Colorado, 7 $\mathrm{km}$ NE of General Cepeda, Coahuila, being one of the most abundant continental species of the Difunta Group.

Melanoides (Melanoides) wollebeni Perrilliat, Vega, Espinosa and Naranjo-García, 2008

Figures 4.16

Description. Shell small, narrowly conic or turriform; whorls flattened on the periphery, with two spiral cords that become three over the body whorl. The upper cord wider, the middle less developed 
and the third cord underdeveloped. Chain of spiral papillae over shoulder. Body whorl with 6 to 7 spiral ribs. Aperture with thick callus over columella. Apex and aperture not well preserved.

Material examined. Four specimens, CPC1038, height $=9.9 \mathrm{~mm}$, width $=3.2 \mathrm{~mm}$, whorls $=7 ;$ CPG-1039, height $=10.3 \mathrm{~mm}$, width $=3.9$ $\mathrm{mm}$, whorls $=4$; CPC-1040, height $=10.3 \mathrm{~mm}$, width $=3.2 \mathrm{~mm}, 8$ whorls; CPG-1041, height $=$ $5.4 \mathrm{~mm}$, width $=2.5 \mathrm{~mm}$, whorls $=6$.

Occurrence. Las Águilas/Porvenir de Jalpa, General Cepeda, Coahuila, Cerro del Pueblo Formation, upper Campanian.

Discussion. The specimens differ from Melanoides (Melanoides) yolandae Perrilliat, Vega, Espinosa and Naranjo-García, 2008, being wider, with weaker tubercles on last whorl spirals. M. (M.) yolandae has two chains of nodules over the entire shell, and the observed specimens of $M$. (M.) wollebeni have only one chain of nodules over the shoulder. The Family Thiaridae is known from Africa, Asia and the Americas. Their closer relatives are the Planaxidae (Morrison, 1954). Thiarids use partenogenetic reproduction and inhabit fresh water (Burch, 1989). The family Thiaridae represents the tropical assemblage of the fauna (Taylor, 1985). Melanoides is also found in Quaternary deposits in northeast Africa and Asia (Williamson, 1981; Leng, et al., 1999). In the Recent, is distributed in southeast Asia, India and South Africa (with 30 species) (De Kock and Wolmarans 2009). Morrison (1954) stated that all species of the genus are ovoviviparous and parthenogenetic. They live in lentic or lotic waters and might be intermediate host of human or animal parasites (Pointier, 1999). In addition, the species Melanoides tuberculata (Müller, 1774) had become an invasive species in new habitats where it is introduced (Gutiérrez-Amador et al., 1995). Nowadays, it is widely spread around the world (Abbott, 1973; Pointier et al., 1993; Contreras-Arquieta and Contreras-Balderas, 2000; Guimarães et al., 2001; Facon et al., 2003). M. tuberculata has a rapid growth and it has numerous offspring. It withstands desiccation and lives in diverse habitats and has a life span of 2 years (Dudgeon, 1989).

Genus Pachymelania Smith, 1893

Pachymelania wyomingensis (Meek, 1873)

Figures $4.17,5.1-5.12$

Description. Shell medium-sized, moderately convex; teleoconch of seven whorls; suture linear; sculpture in last whorls with a prominent, strong spiral rib, outward projecting with tubercles; upper whorls with crenulated longitudinal ribs, crossed by five spiral lines.

Material examined. Eight specimens, see Table 2.

Occurrence. Las Águilas/Porvenir de Jalpa, General Cepeda, Coahuila, Cerro del Pueblo Formation, upper Campanian.

Discussion. This is by far the most abundant continental gastropod from the upper Campanian

Table 2. Measurements of Pachymelania womingensis (Meek, 1873), from the upper Campanian Cerro del Pueblo Formation, Parras Basin.

\begin{tabular}{|c|c|c|c|}
\hline $\begin{array}{c}\text { Catalog } \\
\text { number }\end{array}$ & $\begin{array}{c}\text { Height } \\
\text { mm }\end{array}$ & $\begin{array}{c}\text { Width } \\
\text { mm }\end{array}$ & $\begin{array}{c}\text { Whorls } \\
\text { number }\end{array}$ \\
\hline CPC-2147 & 41.5 & 8.7 & 8 \\
\hline CPC-2148 & 38.6 & 6.9 & 7 \\
\hline CPC-2149 & 37.7 & 8.2 & 9 \\
\hline CPC-2150 & 28.1 & 6.6 & 8 \\
\hline CPC-2151 & 27.2 & 8.8 & 7 \\
\hline CPC-2152 & 30.1 & 7.9 & 7 \\
\hline CPC-2153 & 32.3 & 8.9 & 7 \\
\hline CPC-2154 & 22.8 & 10.2 & 5 \\
\hline CPC-2155 & 30.1 & 6.2 & 7 \\
\hline CPC-2156 & 35.4 & 5.8 & 8 \\
\hline CPC-2157 & 20.8 & 9.5 & 5 \\
\hline CPC-2158 & 33.3 & 8.1 & 7 \\
\hline CPC-2159 & 25.5 & 7.8 & 7 \\
\hline
\end{tabular}




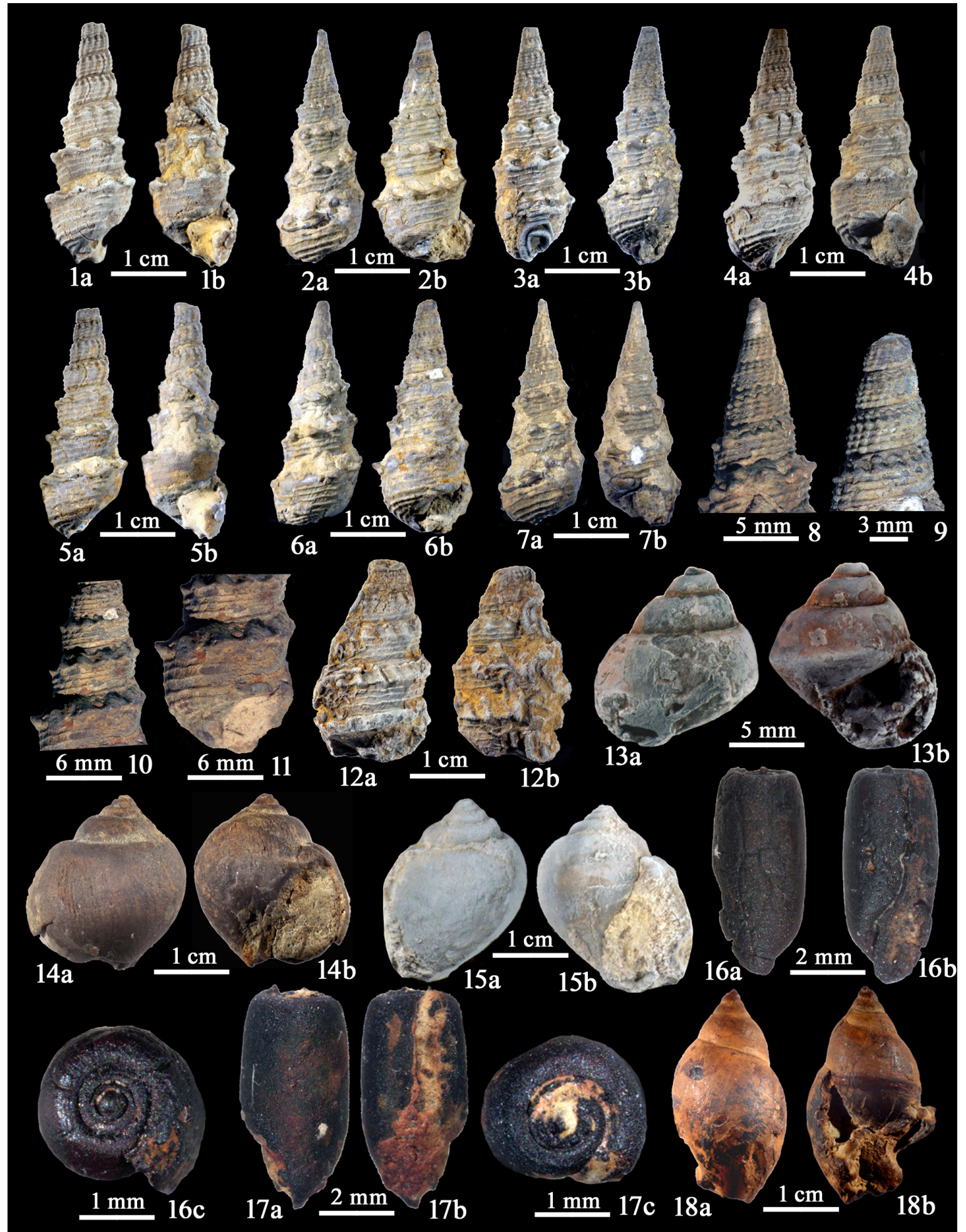

Figure 51 - 12, Pachymelania wyomingensis; 1a, 2148, ad.; 1b, ap.; 2a, 2149, ad.; 2b, ap.; 3a, 2150, ad.; 3b, ap.; 4a, 2151, ad.; 4b, ap.; 5a, 2152, ad.; 5b, ap.; 6a, 2153, ad.; 6b, ap.; 7a, 2154, ad.; 7b, ap.; 8, 2155, spi.; 9, 2156, spi.; 10, 2157, spi.; 11, 2158, ap.; 12a, 2159, ad.; 12b, ap. 13, Littorinidae; 13a, 2161, ad.; 13b, ap. 14, 15, Birgella burchi Naranjo-García and Aguillón, n. sp.; 14a, ho. 1032, ad.; 14b, ap.; 15a, pa. 1033, ad.; 15b, ap. 16, 17, Cylichna sp.; 16a, 2162, ad.; 16b, ap.; 16c, an.; 17a, 2163, ad.; 17b, ap.; 17c, an. 18, Physa sp.; 18a, 1059, ad.; 18b, ap. Coahuila, Cerro del Pueblo Formation, Campanian. Ad = adapertural, an = anterior, ap $=$ apertural, $h o=h o l o t y p e, ~ p a=p a r a t y p e$, spi $=$ spire. 
Cerro del Pueblo Formation. Some specimens have attached serpulid worms and ostreoids, suggesting an estuarine habitat. This species was also reported from the Maastrichtian Laramie Formation of Colorado (Hartman, 1998) and Wyoming (Taylor, 1975).

Superfamily Epitonioidea Berry, 1910

Family Epitoniidae Berry, 1910

Genus Acirsa Mørch, 1857

Acirsa cf. A. gravida Sohl, 1964

Figure 4.12

Description. Shell medium-sized, moderately convex; teleoconch of five whorls; suture linear; sculpture in last whorls with a prominent, strong spiral rib, outward projecting with tubercles; upper whorls with crenulated longitudinal ribs, crossed by five spiral lines.

Material examined. One specimen, CPC-2160, height $=23.2 \mathrm{~mm}$, width $=8.4 \mathrm{~mm}$, whorls $=5$.

Occurrence. Las Águilas/Porvenir de Jalpa, General Cepeda, Coahuila, Cerro del Pueblo Formation, upper Campanian.

Discussion. This species was reported from the Maastrichtian Coffee Sand of Mississippi (Sohl, 1964).

\section{Superfamily Littorinoidea Children, 1834 \\ Family Littorinidae Children, 1834 \\ Genus indeterminate}

Figure 5.13

Description. Small trochiform shell, protoconch not preserved, spire with three whorls; narrow umbilicus; aperture wide, subovate.

Material examined. One specimen, CPC-2161, height $=15.1 \mathrm{~mm}$, width $=18.6 \mathrm{~mm}$, whorls $=3$. Occurrence. Las Águilas/Porvenir de Jalpa, General Cepeda, Coahuila, Cerro del Pueblo Formation, upper Campanian.

Discussion. The single specimen is poorly preserved and a more detailed identification is not possible.
Superfamily Rissooidea Gray, 1847

Family Hydrobiidae Stimpson, 1865

Genus Birgella Baker, 1926

Birgella burchi Naranjo-García and Aguillón, new species

Figures 5.14, 5.15

Diagnosis. Shell small, globose; growth lines marked; small umbilicus with lip of columella bent over; aperture roundly-lunate.

Description. Shell globose, small, round whorls, slightly indented suture. Growth lines marked, more so, near to suture. Apex unknown, lip of columella bent over the small umbilicus. Aperture roundly lunate. Height of aperture about twothirds the height of shell.

Material examined. Two specimens, holotype CPC-1032, height $=8.5 \mathrm{~mm}$, width $=8.5 \mathrm{~mm}$, whorls $=6$; paratype CPC-1033, height $=7.4$ $\mathrm{mm}$, width $=7.4 \mathrm{~mm}$ whorls $=5$.

Occurrence. Las Águilas/Porvenir de Jalpa, General Cepeda, Coahuila, Cerro del Pueblo Formation, upper Campanian.

Discussion. Birgella burchi n. sp. is closer to B. subglobosa (Say, 1825), a Recent species from the Great Lakes, United States. The species differ in the size, with $B$. burchi n. sp. being taller. In $B$. subglobosa the aperture is round and less than two-thirds the height of shell. It possesses fewer whorls (4), the suture is more deeply marked and the whorl of the spire has a shoulder. B. subglobosa has also an umbilicus with a straight lip of the columella. In B. burchi n. sp., the spire is shorter and the aperture taller. The width and height of the shell are equal, while B. subglobosa is taller than wide. The Family Hydrobiidae is widely distributed and common around the world in temperate, subtropical, and tropical regions. The vast majority of species inhabit freshwater bodies, although few inhabit brackish water (Burch, 1989). Recent molecular-based studies (Wilke et al., 2013) strongly support the monophyly of the family Hydrobiidae, which is part of the big and taxonomically problematic superfamily Rissooidea. For the moment, Wilke et al. (2013) 
remarked that more in-depth studies are needed to identify its sister group relationships. The Hydrobiidae is distributed in western Palearctic, eastern Nearctic, northern Neotropic and in South Africa (Wilke et al., 2013).

Etymology. The species is named after Dr. John B. Burch, who had greatly contributed to the knowledge of freshwater mollusks of North America.

Order Cephalaspidea Fischer, 1883

Superfamily Cylichnoidea Adams and Adams, 1854

Family Cylichnidae Adams and Adams, 1854 Genus Cylichna Lovén, 1847 Cylichna sp.

Figures 5.16, 5.17

Description. Shell small, slender, rounded at inferior extremity, subtruncated above. Shell smooth. Aperture long. Columella twisted and bears weak fold.

Material examined. Two specimens, CPC2162 , height $=6.5 \mathrm{~mm}$, width $=2.9 \mathrm{~mm}$; hypotype CPC-2163, height $=7.2 \mathrm{~mm}$, width $=2.9 \mathrm{~mm}$.

Occurrence. Las Águilas/Porvenir de Jalpa, General Cepeda, Coahuila, Cerro del Pueblo Formation, upper Campanian.

Discussion. Perrilliat et al. (2000) reported Cylichna secalina Shumard, 1861 from the late Maastrichtian Mexcala Formation of Guerrero, Southern Mexico. The species was originally reported from the Upper Cretaceous Nacatoch Sand of Texas and the Ripley Formation of Mississippi. The poor preservation of the specimens here reported prevents a specific determination.

Order Basommatophora Schmidt, 1855 Superfamily Planorboidea Rafinesque, 1815 Family Physidae Fitzinger, 1833

Figures 6.16, 6.17

Description. Shell small, elongate; protoconch unknown; teleoconch of five whorls, flat; suture chanelled; surface smooth; aperture not preserved.
Material examined. Two specimens, CPC-2164, height $=8.1 \mathrm{~mm}$, width $=2.6 \mathrm{~mm}$, whorls $=4$; CPG-2165, height $=10.1 \mathrm{~mm}$, width $=5.4 \mathrm{~mm}$, whorls $=4$.

Occurrence. Las Águilas/Porvenir de Jalpa, General Cepeda, Coahuila, Cerro del Pueblo Formation, upper Campanian.

Discussion. The specimens resemble Bulinus sp. 4, reported by Perrilliat et al. (2008, p. 264, fig. $5.16,5.17)$ from the upper Campanian Cerro del Pueblo Formation at General Cepeda, Coahuila.

Genus Physa Draparnaud, 1801 Physa sp.

Figure 5.18

Description. Shell sinistral, oval, of medium size, with marked growth lines over the body whorl (just in one specimen), whorls slightly swollen, suture slightly indented, shiny shell surface, apex and aperture of shell not present.

Material examined. Ten specimens, see Table 3.

Occurrence. Las Águilas/Porvenir de Jalpa, General Cepeda, Coahuila, Cerro del Pueblo Formation, upper Campanian.

Discussion. Physa sp. resembles some forms of P. acuta Draparnaud, 1805, in particular that from Connecticut, Litchfield County, Salisbury, north

Table 3. Measurements of Physa sp., from the upper Campanian Cerro del Pueblo Formation, Parras Basin.

\begin{tabular}{|c|c|c|c|c|}
\hline $\begin{array}{c}\text { Catalogue } \\
\text { number }\end{array}$ & Type & $\begin{array}{c}\text { Height } \\
\text { mm }\end{array}$ & $\begin{array}{c}\text { Width } \\
\text { mm }\end{array}$ & $\begin{array}{l}\text { Whorls } \\
\text { number }\end{array}$ \\
\hline CPC- 1,059 & Hypotype & 19.2 & $\begin{array}{c}10.5 \\
\text { compressed specimen }\end{array}$ & 5 \\
\hline CPC- 1,060 & Hypotype & 15.8 & $\begin{array}{c}7.5 \\
\text { compressed specimen } \\
\text { and cast }\end{array}$ & $31 / 2$ \\
\hline CPC-1,061 & Hypotype & 15.5 & 8.0 cast & $41 / 2$ \\
\hline CPC-1,062 & Hypotype & 15 & 9.1 cast & $31 / 2$ \\
\hline CPC-1,063 & Hypotype & 14.9 & 8.5 & $51 / 2$ \\
\hline CPC-1,064 & Hypotype & 14.7 & 8.7 cast & $21 / 2$ \\
\hline CPC-1,065 & Hypotype & 13.5 & $\begin{array}{c}6.1 \\
\text { compressed specimen }\end{array}$ & $51 / 2$ \\
\hline CPC-1,066 & Hypotype & 10.1 & $\begin{array}{l}4.9 \\
\text { compressed specimen } \\
\text { and collapsed over itself }\end{array}$ & 5 \\
\hline CPC-1,067 & Hypotype & 9 & $\begin{array}{l}4.9 \\
\text { collapsed over itself }\end{array}$ & 5 \\
\hline CPC-1,068 & Hypotype & 8.9 & 4.8 & 4 \\
\hline
\end{tabular}




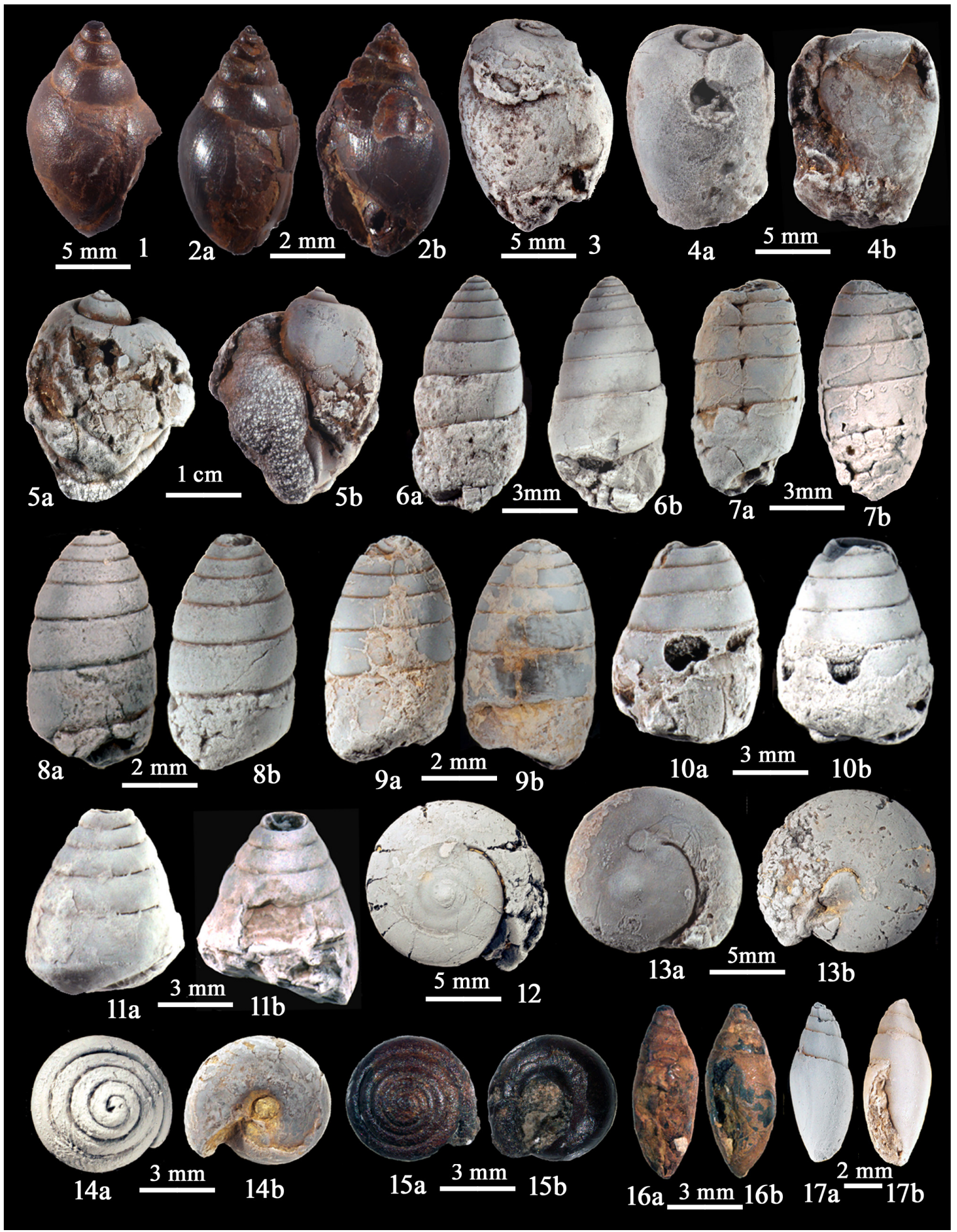

Figure 6 1, 2, Haitia taylori Naranjo-García and Aguillón, n. sp.; 1, pa. 1070, ad.; 2a, ho. 1069, ad.; 2b, ap. 3 - 5, Mesolanistes sp.; 3, 2166 , ad.; 4a, 2167, ad.; 4b, ap.; 5a, 2168, ad.; 5b, ap. 6 - 9, Holospira thompsoni Naranjo-García and Aguillón, n. sp.; 6a, ho. 1,071, ad.; 6b, ap.; 8a, pa. 1,072, ad.; 8b, ap.; 9a, pa. 1,073, ad.; 9b, ap. 10, 11 , Holospira sp.; 10a, 1,074, ad.; 10b, ap.; 11 a, 1,075, ad.; 11 b, ap. 12, 13, Helicidae; 12, 2169, an.; 13a, 2170 , an.; 13b, po. 14, 15, Zonitidae; 14a, 2171, an.; 14b, po.; 15a, 2172 , an.; 15b, po. 16, 17, Physidae; 16a, 2164 , ad.; 16b, ap.; 17a, 2165, ad.; 17b, ap. Coahuila, Cerro del Pueblo Formation, Campanian. Ad = adapertural, an = anterior, ap = apertural, ho = holotype, $\mathrm{pa}=$ paratype, $\mathrm{po}=$ posterior . 
shore of Lake Wononscopomuc (Taylor, 2003). However, our specimens of Physa sp. reach higher sizes and $P$. acuta from Lake Wononscopomuc is 13.5 to $12.2 \mathrm{~mm}$ in height. In Physa sp. the aperture of the shell inserts in the body whorl at about half the height of the shell, while in P. acuta from Lake Wononscopomuc the aperture inserts in the first third of the body whorl.

\section{Genus Mesolanistes Yen, 1945 \\ Mesolanistes sp.}

Figures $6.3-6.5$

Description. Shell small to medium-sized, ovate; commonly with moderately elevated spire of three whorls but depressed in some specimens; suture incised; last whorl enlarging rapidly; aperture ovate; sculpture of fine axial ribs.

Material examined. Three specimens, CPC2166 , height $=28.1 \mathrm{~mm}$, width $=26.6 \mathrm{~mm}$, whorls $=3$; CPC-2167, height $=30.2 \mathrm{~mm}$, width $=25.6$ $\mathrm{mm}$, whorls $=3$; CPC-2168, height $=42.5 \mathrm{~mm}$, width $=33.6 \mathrm{~mm}$, whorls $=3$.

Occurrence. Las Águilas/Porvenir de Jalpa, General Cepeda, Coahuila, Cerro del Pueblo Formation, upper Campanian.

Discussion. Perrilliat et al. (2008) described two species of Mesolanistes from the upper Campanian Cerro del Pueblo Formation, in outcrops found near Rincón Colorado, Coahuila. The specimens here reported cannot be assigned to any of those species, due to the poor preservation of the hematized remains.

Genus Haitia Clench and Aguayo, 1932

Haitia taylori Naranjo-García and Aguillón, new species

Figures 6.1, 6.2

Diagnosis. Shell broadly conic, small, sinistral; growth lines marked; height of aperture half the height of shell.
Description. Small, sinistral shell; broadly conic; whorls somewhat round ; suture slightly indented, growth lines marked. Apex not preserved. Height of aperture about half the height of shell, aperture not preserved.

Material examined. Two specimens, holotype CPC-1069, height $=7.62 \mathrm{~mm}$, width $=4.15 \mathrm{~mm}$, whorls $=61 \frac{1}{2}$; paratype CPC-1070, height $=6.96$ $\mathrm{mm}$, width $=3.55 \mathrm{~mm}$, whorls $=6$.

Occurrence. Las Águilas/Porvenir de Jalpa, General Cepeda, Coahuila, Cerro del Pueblo Formation, upper Campanian.

Discussion. Haitia taylori n. sp. resembles H. pomilia (Conrad, 1834) of Alabama, Randons Creek, near Clairborne, Monroe County of the Recent (Taylor, 2003). These species are alike in the general shape of the shell. The height of the aperture reaches over half the lenght of the shell but both species differ in size; $H$. pomilia is over two times the size of $H$. taylori, which is less globose than $H$. pomilia. The Physidae are found from the northern temperate to the Arctic, as well as throughout the Americas. These freshwater mollusks live in small to large water bodies (ditches, ponds, lakes, brooks and rivers). The genus Physa is distributed from Eurasia, in the temperate and Arctic zone, and in North America (Taylor, 2003). Today some species of Physa became invasive in places where they have been introduced, for example Physa acuta Draparnaud, 1805 is found in Europe, Africa, some places in Asia, Australia, and South Africa (Pointier and Marquet, 1990; Appleton, 2003; Guo et al., 2009; Zukowski and Walker 2009; Van Leeuwen et al., 2013). In addition, the genus Haitia is part of the fauna of the temperate and tropical areas of North America, the Antilles, Colombia, and the western side of South America, from Peru to middle Chile (Taylor, 2003). Physids can be found in all types of freshwater habitats (Burch, 1989).

Etymology. Named after the late Dr. Dwight W. Taylor, who dedicated much of his life to the study of the family Physidae. 
Order Stylommatophora Schmidt, 1855

Superfamily Urocoptoidea Uit de Weerd, 2008

Family Holospiridae Pilsbry, 1946

Holospira von Martens in Albers, 1860

Holospira thompsoni Naranjo-García and Aguillón, new species

Figures $6.6-6.9$

Diagnosis. Shell subcylindrical, small, 7 to 8 whorls; suture nearly linear, surface smooth.

Description. Shell small, subcylindrical, obtuse apex, 7 to 8 whorls, compactly coiled firsts three whorls, the other four or five more loosely coiled; suture nearly linear. Surface smooth. Aperture unknown.

Material examined. Three specimens, holotype CPC-1071, height $=12.3 \mathrm{~mm}$, width $=6.4 \mathrm{~mm}$, whorls $=7$; (two compressed specimens) paratype CPC-1072, height $=14.4 \mathrm{~mm}$, whorls $=8$ remaining; paratype CPG-1073, height $=13.1$ $\mathrm{mm}$, whorls $=7$.

Occurrence. Las Águilas/Porvenir de Jalpa, General Cepeda, Coahuila, Cerro del Pueblo Formation, upper Campanian.

Discussion. Holospira thompsoni $\mathrm{n}$. sp. differs from Holospira sp. from Temalac, Guerrero, Lower Maastrichian, Mexcala Formation (Perrilliat et al., 2000) in the general shape of the shell which in Holospira sp. is subcylindrical with the obtuse apex, and has compactly coiled whorls, while in $H$. thompsoni $\mathrm{n}$. sp. whorls grow slower and are ample. They also differ in size, being 9.5 to $12.1 \mathrm{~mm}$ in Holospira sp. while in $H$. thompsoni its height is 12.3 to $14.4 \mathrm{~mm}$. Holospiridae are terrestrial pulmonate gastropods that inhabit submesic and xeric environments, from southern United States (south Texas, New Mexico and Arizona) to the north of Oaxaca (mid Mexico). They require limestone or dolomite terrains and their distribution is in narrow areas (Thompson and Mihalcik, 2005).

Etymology. Holospira thompsoni n. sp. is named after the late Fred G. Thompson of the University of Florida, because of his enormous contributions to the knowledge of the Central American non-marine mollusks of the area.

\section{Holospira sp.}

Figures 6.10, 6.11

Description. Shell of medium size, ovate-conic, apex absent, 5 whorls remaining, it has very narrow whorls near the apex, increasing relatively faster in width toward the aperture. Whorls flattened, suture slightly indented. Surface smooth, aperture not preserved.

Material examined. Two specimens, CPC1074 , height $=8.1 \mathrm{~mm}$, width $=6.7 \mathrm{~mm}$, whorls $=5 ;$ CPC-1075, height $=8.5 \mathrm{~mm}$, width $=6.1$ $\mathrm{mm}$, whorls $=5$.

Occurrence. Las Águilas/Porvenir de Jalpa, General Cepeda, Coahuila, Cerro del Pueblo Formation, upper Campanian.

Discussion. Holospira sp. differs from other Recent species in the shape of the first whorls, including $H$. mesolia from Sanderson, Terrell County, Texas, United States (Pilsbry, 1946) and $H$. pasonis Dall, 1895 of Mule canyon, El Paso County, Texas, United States (Pilsbry, 1946). However, it is not possible to assign this Holospira to any other known species or subgenera of the genus Holospira, which differ in the inside of the columella and in the presence or absence of lamellae (Thompson, 2011). Additionally, specimens are incomplete or they could be of juvenile age, and measure 8.1 and $8.5 \mathrm{~mm}$ and have 5 whorls. H. mesolia has a height that goes from 20 to $23.5 \mathrm{~mm}$ and has $12^{3 / 4}$ to 14 whorls, H. pasonis has a height of 22.3 to $24.7 \mathrm{~mm}$ and has 11 to 11 1/2 whorls.

For Recent specimens of the genus Holospira the geographical distribution ranges from Texas, Arizona, New Mexico (Pilsbry, 1946) to most of Mexico (except The Peninsula of Baja California, Chiapas, Tabasco, Campeche and Yucatán) The genus Holospira gets to Oaxaca at about 29 degrees of latitude (Bequaert and Miller, 1973). Fossil specimens of the family Holospiridae date back to the New Mexico Paleocene (Cockerell, 1914), Lower Maastrichtian (Mexcala Formation), Temalac, Guerrero, Mexico (Perrilliat et al., 2000), and the Tertiary deposits of Wyoming (Henderson, 1935). In the Recent the Family Holospiridae is 
distributed from the states of Arizona, New Mexico, and Texas to central Mexico, these terrestrial snails today live and are abundant in dry climates where there are limestone and dolomite beds (Thompson and Mihalcik, 2005). The genus Holospira is known to inhabit the Recent from western Arizona, New Mexico and Texas in the United States to northern Oaxaca, Mexico (Thompson, 2011). Holospira spp. are usually found in limestone outcrops, where colonies have several individuals (Bequaert and Miller, 1973).

\section{Superfamily Helicoidea Rafinesque, 1815 Family Helicidae Rafinesque 1815 \\ Figures 6.12, 6.13}

Description. Small, discoidal and compressed shell; umbilicus narrow; aperture not preserved.

Material examined. Two specimens, CPC2169 , height $=4.8 \mathrm{~mm}$, width $=16.2 \mathrm{~mm}$, whorls $=5 ;$ CPC-2170, height $=4.5 \mathrm{~mm}$, width $=14.4$ $\mathrm{mm}$, whorls $=5$.

Occurrence. Las Águilas/Porvenir de Jalpa, General Cepeda, Coahuila, Cerro del Pueblo Formation, upper Campanian.

Discussion. The hematized specimens represent the first record of helicid snails for the upper Campanian Cerro del Pueblo Formation.

Superfamily Zonitoidea Mørch, 1864 Family Zonitidae Mørch, 1864

Figures 6.14, 6.15

Description. Shell small, smooth, trochoid; umbilicus narrow.

Material examined. Two specimens, CPC2171 , height $=4.1 \mathrm{~mm}$, width $=5.4 \mathrm{~mm}$, whorls $=5 ;$ CPC-2172, height $=3.9 \mathrm{~mm}$, width $=5.1$ $\mathrm{mm}$, whorls $=5$.

Occurrence. Las Águilas/Porvenir de Jalpa, General Cepeda, Coahuila, Cerro del Pueblo Formation, upper Campanian.
Discussion. The specimens are very small and their preservation prevents offering a more precise identification.

\section{Conclusions}

The great diversity and abundance of continental mollusks found in the upper Campanian Cerro del Pueblo Formation is related to the paralic environments whose outcrops are found in a broad area. Their distribution includes several localities found west of Saltillo to north of the Parras Basin, near the border with the La Popa Basin. The lithology of these areas was controlled by mainly salt tectonics that formed small sub-basins, where brackish and freshwater environments prevailed during Paleocene times. Although the preservation of the shell of many species of continental gastropods from the Difunta Group can be acceptable, the main problem relies on that modern systematics of continental gastropods is based mainly on softbody morphology and more recently, molecular biology. This report is presented in the hope that it can be useful as foundation for future work on paleoecology and evolution of the continental mollusk communities during the Late Cretaceous and Paleogene.

\section{Acknowledgements}

Our sincere gratitude to Tom Musselman and Sandra Ramos-Amézquita for detailed review of the final manuscript, and to José Manuel Padilla (Museo del Desierto) for curatorial support. We thank Francisco Javier Valencia-Santana for his help in the laboratory. Thanks also to INAH Coahuila and Felipe Rodríguez for their kind support. Special thanks to Laura Luna (Instituto de Geología, UNAM) for her support with figures. 


\section{References}

Abbott, R.T., 1973, Spread of Melanoides tuberculata: The Nautilus, 87(1), 1-29.

Adams, H., Adams, A., 1854, The genera of recent Mollusca, arranged according to their organization: London, U.K., van Voorst, 1, 257-484.

Albers, J.C., 1860, Die Heliceen, nach natürlicher Verwandtschaft systematische geordnet: Leipzig, Germany, Wilhelm Engelmann, 359 p.

Anthony, J.G., 1854, Descriptions of new fluviatile shells of the genus Melania Lamarck, from the western states of North America: Annual Report of the Lyceum of Natural History of New York, 6, 80-13.

Appleton, C.C., 2003, Alien and invasive fresh water Gastropoda in South Africa: African Journal of Aquatic Science, 28(1), 69-81.

Baker, F.G., 1926, Nomenclatorial Notes on American Fresh Water Mollusca: Transactions of the Wisconsin Academy of Sciences, Arts and Letters, 22, 193-205.

Bandel, K., Riedel, F., 1994, The Late Cretaceous gastropod fauna from Ajka (Bakony Mountains, Hungary): a revision: Annalen des Naturhistorisches Museum in Wien, 96A, $1-65$.

Barton, K.E., Howell, D.G., Vigil, J.F., 2003, The North America Tapestry of Time and Terrain (online): Denver, Colorado, U.S. Geological Survey, last modified September 24, 2009, available in <https://pubs.usgs. gov/imap/i2781/>, access September 2017.

Bequaert, J.C., Miller, W.B., 1973, The mollusks of the arid Southwest: with an Arizona Check list: Tucson, U.S.A., The University of Arizona Press, $271 \mathrm{p}$.

Bouchet, P., Rocroi J.-P., Hausdorf, B., Kaim, A., Kano, Y., Nützel, A., Parkhaev, P., Schrödl, M., Strong, E.E., 2017, Revised classification, nomenclator and typification of gastropod and monoplacophoran families: Malacologia, 61(1-2), 1-526.

Bowdich, E., 1822, Elements of conchology, Vol. I: Including the fossil genera and the animals; Univalves: London, U.K., Treuttel \& Würtz, $1-83$.

Burch, J.B., 1988, North American Freshwater Snails. Introduction, systematics, nomenclature, identification, morphology, habitats, distribution: Walkerana, 2, 1-80.

Burch, J.B., 1989, North American freshwater snails: Hamburg, U.S.A., Malacological Publications, $365 \mathrm{p}$.

Children, J.G., 1834, Mollusca, in Synopsis of the contents of the British Museum: London, U.K., British Museum, 88-118.

Clench, W.J., Aguayo, C.G., 1932, New Haitian mollusks: Proceedings of the New England Zoological Club, 13, 35- 38.

Cockerell, T.D.A., 1914, Tertiary Mollusca from New Mexico and Wyoming: Bulletin of the American Museum of Natural History, 33, 101-107.

Conrad, T.A., 1834, Description of some new species of freshwater shells from Alabama, Tennessee \&c: American Journal of Science and Arts, 25, 338-343.

Contreras-Arquieta, A., Contreras-Balderas, S., 2000, Description, biology, and ecological impact of the screw snail, Thiara tuberculata (Müller, 1774) (Gastropoda: Thiaridae) in Mexico, in Claudi, R., Leach, J.H. (eds.), Nonindigenous freshwater organisms, vectors, biology, and impacts: Boca Raton, U.S.A., Lewis Publishers, 151-160.

Cox, L.R., 1959, Thoughts on the classification of the Gastropoda: Proceedings of the Malacological Society of London, 33, 239-261.

Cuvier, G., 1797, Tableau élémentaire de l'histoire naturelle des animaux: Paris, France, Baudouin, 710 p. 
Dall, W.H., 1895, On a new species of Holospira from Texas: The Nautilus, 8(10), 112.

Dall, W.H., 1910, Report on a collection of shells from Peru, with a summary of the littoral marine Mollusca of the Peruvian zoological province: The Nautilus, 23(10), 130-132.

De Kock, K.N., Wolmarans, G.T., 2009, Distribution and habitats of Melanoides tuberculata (Müller, 1777) and M. victoriae (Dorhn 1865) (Mollusca: Prosobranchia: Thiaridae) in South Africa: Water South Africa, 35(5), 713-720.

Draparnaud, J.P.R., 1801, Tableau des mollusques terrestres et fluviátiles de la France: Paris, France, 1Arthus Bertrand, $16 \mathrm{p}$.

Draparnaud, J.P.R., 1805, Histoire Naturelle des Mollusques Terrestres et Fluviatiles de la France, ouvrage posthume: Paris, France, Colas \& Gabon, 164 p.

Dudgeon, D., 1989, Ecological strategies of Hong Kong Thiaridae (Gastropoda: Prosobranchia): Malacologicial Review, 22, 39-53.

Eberth, D.A., Delgado-de Jesús, G.R., Lerbekmo, J.F., Brinkman, D.B., Rodríguez-de la Rosa, R.A., Sampson, S.D., 2004, Cerro del Pueblo Fm (Difunta Group, Upper Cretaceous), Parras Basin, southern Coahuila, Mexico: Reference sections, age, and correlation: Revista Mexicana de Ciencias Geológicas, 21(3), 335-352.

Facon, B., Pointier, J.P., Glaubrecht, M., Poux, C., Jarne, P., David, P., 2003, A molecular phylogeography approach to biological invasions of the new world by parthenogenetic thiarid snails: Molecular Ecology, 12, 3027-3039.

Fischer, P., 1880-1887, Manuel de Conchyliologie et de Paléontologie Conchyliologique: Paris, France, Savy, Fasc. 1, 1-112 [21. 9. 1880]; Fasc. 2, 113-192 [16. 3. 1881]; Fasc. 3, 193304 [28. 7. 1881]; Fasc. 4, 305-416 [5. 5.
1882]; Fasc. 5, 417-512 [21. 2. 1883]; Fasc. 6, 513-608 [20. 12. 1883]; Fasc. 7, 609-688 [30. 6. 1884]; Fasc. 8, 689-784 [29. 1. 1885]; Fasc. 9, 785-896 [31. 8. 1885]; Fasc. 10, 8971008 [30. 4. 1886]; Fasc. 11, 1009-1369 [15. 6. 1887].

Fischer, P., 1885, Manuel de Conchyliologie et de Paléontologie Conchyliologique: Paris, France, Savy, Fasc. 8, 689-784.

Fischer, P.H., Crosse, H., 1870-1902, Études sur les mollusques terrestres et fluviatiles du Mexique et du Guatemala, in MilneEdwards, H. (ed.), Mission scientifique au Mexique et dans l'Amérique Centrale. Recherches zoologiqués, Partie 7: Paris, France, Imprimierie Imperiale, 1-731.

Fitzinger, L.I., 1833, Systematisches Verzeichniss der im Erzherzogthume Oesterreich vorkommenden Weichthiere, als Prodrom einer Fauna desselben: Oesterreich, Beiträge zur Landeskunde Oesterreich's unter der Enns, 3, 88-122.

Fleming, J., 1822, The philosophy of zoology, a general view of the structure, functions and classification of animals: Edinburgh, U.K., Constable \& Co., 2, 618 p.

Forbes, E., 1845, On the fossil shells collected by Mr. Lyell from the Gretaceous Formations of New Jersey: Geological Society of London, Quarterly Journal, 1, 61-64.

Giles, K.A., Lawton, T.F., 1999, Attributes and evolution of an exhumed salt weld, La Popa basin, northeastern Mexico: Geology, 27, 323-326.

Giles, K.A., Lawton, T.F., 2002, Halokinetic sequence stratigraphy adjacent to the El Papalote diapir, northeastern Mexico: American Association of Petroleum Geologists Bulletin, 86(5), 823-840.

Gill, T., 1871, Arrangement of the families of mollusks: Washington, D.C., Smithsonian Miscellaneous Collections, 227, 1-49. 
Grabau, A.W., Shimer, H.W., 1909, North American index fossils invertebrates: New York, U.S.A., A. G. Seiler, 1, 853 p.

Gray, J.E., 1847, A list of the genera of Recent Mollusca, their synonymia and types: Proceedings of the Zoological Society of London, 15, 129-242.

Guimarães, C.T., Pereira de Souza, G., de Moura Soares, D., 2001, Possible competitive displacement of planorbids by Melanoides tubeculata in Minas Gerais, Brazil: Memorias Instituto Oswaldo Cruz, Rio de Janeiro, 96 (Suppl.), 173-176.

Guo, Y., Hwang, G.-C., He, H., 2009, Expansion of an invasive freshwater snail Physa acuta (Gastropoda: Physidae) in China: Molluscan Research, 29(3), 174-178.

Gutiérrez-Amador, A., Perera de Puga, G., YongCong, M., Ferrer-López, J.R., SánchezNoda, J., 1995, Distribución y posible competencia entre Melanoides tuberculata y Tarebia granifera (Prosobranchia: Thiaridae) en el lago Hanabanilla, Cuba: Revista Cubana de Medicina Tropical, 47(2), 93-99.

Hartman, J.H., 1998, The stratigraphy of the Mesozoic and Early Cenozoic nonmarine molluscs of Colorado: Proceedings of the Denver Museum of Natural History, series 3, 14, 1-14.

Henderson, J., 1935, Fossil non-marine Mollusca of North America: Geological Society of America, Special Papers, 3, 313 p.

Lawton, T.F., Vega, F.J., Giles, K.A., RosalesDominguez, C., 2001, Stratigraphy and origin of the La Popa basin, Nuevo Leon and Coahuila, Mexico, in Bartolini, C., Buffler, R.T., Cantú-Chapa, A. (eds.), Mesozoic and Cenozoic evolution of the western Gulf of Mexico basin: tectonics, sedimentary basins and petroleum systems: American Association of Petroleum Geologists, Memoir 75, 219-240.

Lawton, T.F., Bradford, I.A., Vega, F.J., Gehrels, G.E., Amato, J.M., 2009, Provenance of Upper Cretaceous-Paleogene sandstones in the foreland basin system of the Sierra Madre Oriental, northeastern Mexico, and its bearing on fluvial dispersal systems of the Mexican Laramide Province: Geological Society of America Bulletin, 121, 820-836.

Lea, I., 1862, Description of a New Genus (Goniobasis) of the Family Melanidae and Eighty-Two New Species: Proceedings of the Philadelphia Academy of Natural Sciences, 14, 262-272.

Leng, M., Lamb, J.A.L., Lamb, H.F., Telford, R.J., 1999, Paleoclimatic implications of isotopic data from modern and early Holocene shells of the freshwater snails Melanoides tuberculata, from lakes in the Ethiopian Rift Valley: Journal of Paleolimnology, 21, 97-106.

Lovén, S.L., 1847, Malacozoologi, öfversigt af Kongliga Vetenskaps-Akademiens Förhandlingar: Stockholm, Sweden,Norstedt \& Soner, 4, 175-199.

McBride, E.F., Weidie, A.E.,Jr., Wolleben, J.A., Laudon, R.G., 1974, Stratigraphy and structure of the Parras and La Popa Basins, northeastern Mexico: Geological Society of America Bulletin, 84(1), 603-622.

Meek, F.B., 1860, Description of new fossil remains collected in Nebraska and Utah: Proceedings of the Academy of Natural Sciences Philadelphia, 12, 308-315.

Meek, F.B., 1873, Preliminary paleontological report, consisting of lists and descriptions of fossils, with remarks on the rocks in which they were found, in Hayden, F.V. (ed.), Sixth Annual Report of the United States Geological Survey of Territories: Washington, D.G., U.S.A., Government Printing Office, 431-518.

Meek, F.B., 1877, Paleontology. United States Geological Exploration of the Fortieth Parallel (King Survey), Report, 4(1), 1-97.

Mørch, O.A., 1864, Fortegnelse over de i Danmark forekommende Land- og Ferskvandbløddyr: Videnskabelige Meddelelser fra den Naturhistorisk Forening i Kjöbenhavn, 1722(1863), 265-367. 
Mørch, O.A., 1857, Fortegnelse over Grønlands Bløddyr, in Rink, H., Grønland geographisk og statistik beskrivet: Copenhagen, Denmark, Louis Klein, 75-100.

Mørch, O.A., 1875, Synopsis familiae Scalidarum Indiarum occidentalium. Oversigt over Vestindiens Scalarier: Videnskabelige Meddelelser fra den Naturhistoriske Forening i Kjöbenhavn, 1874(17), 250-268.

Morrison, J.P.E., 1954, The relationships of Old and New world melanians: Proceedings of the United States National Museum, 103(3325), 357-394.

Müller, O.F., 1774, Vermivm terrestrium et fluviatilium, seu animalium infusoriorum, helminthicorum, et testaceorum, non marinorum, succincta historia: Voluminis Imi pars altera, Havniæ \& Lipsiæ, Heineck \& Faber, 1-72.

Olivier, G.A., 1804, Voyage dans l'Empire Othoman, l'Egypte et la Perse, fait par ordre du gouvernement pendant les six premières années de la République, Tome 2 (with atlas): Paris, France, Henri Agasse, 462 p.

Pacaud, J.-M., Harzhauser, M., 2012, Jponsia, Moniquia et Eginea, trois nouveaux genres de Pachychilidae (Gastropoda, Caenogastropoda) du Paléogène européen: Annales du Muséum d'histoire naturelle de Nice, XXVII, 105-153.

Perrilliat, M.C., Vega, F.., Corona, R., 2000, Early Maastrichtian Mollusca from the Mexcala Formation of the state of Guerrero, southern Mexico: Journal of Paleontology, 74(1), 7-24. Perrilliat, M.C., Vega, F.J., Espinosa, B., Naranjo-García, E., 2008, Late Cretaceous - Early Tertiary Freshwater Gastropods from Northeastern Mexico: Journal of Paleontology, 82(2), 255-266.

Pilsbry, H.A., 1946, Land Mollusca of North, America (North of Mexico): The Academy of Natural Sciences of Philadelphia, Monographs 3, 2(1), 111-158.

Pointier,J.P., 1999, Invading freshwater gastropods: some conflicting aspects for public health:
Malacologia, 41(2), 403-411.

Pointier, J.P., Marquet, G., 1990, Taxonomy and distribution of freshwater mollusks of French Polinesia: Venus (Japanese Journal of Malacology), 49(3), 215-231.

Pointier, J.P., Thaler, L., Pernot, A.F., Delay, B., 1993, Invading freshwater snails and biological control in Martinique Island, French West Indies: Memorias Instituto Oswaldo Cruz, Rio de Janeiro, 96(Suppl.), 67-74.

Ponder, W.F., Lindberg, D.R., 1997, Towards a phylogeny of gastropod molluscs: an analysis using morphological characters: Zoological Journal of the Linnean Society, 119(2), 83-265.

Rafinesque, C.S., 1815, Analyse de la nature, ou Tableau de l'univers et des corps organisées: Palermo, France, l'Imprimerie de Jean Barravecchia, $224 \mathrm{p}$.

Rafinesque, C.S., 1818, Discoveries in natural history, made during a journey through the western region of the United States: American Monthly Magazine and Critical Review, 3, 354-356.

Repelin, J., 1902, Description des faunes et des gisements du Cénomanien saumatre ou d' eau douce du Midi de la France: Annales du Musée d'Histoire naturelle de Marseille, 7(2), $112 \mathrm{p}$

Say, T., 1825, Descriptions of some new species of fresh water and land shells of the United States: Journal of the Academy of Natural Sciences of Philadelphia, 5, 119-131.

Schmidt, A., 1855, Der Geschlechtsapparat der Stylommatophoren in taxonomischer Hinsich: Abhandlungen des Naturwissenschaftlichen Vereins für Sachsen und Thueringen in Halle, 1, 1-52.

Shumard, B.F., 1861, Descriptions of new Cretaceous fossils from Texas: Proceedings of the Boston Society of Natural History, 8, 188-205.

Simone, L.R.L., 2006, Land and freshwater molluscs of Brazil: an illustrated inventory on the Brazilian malacofauna, including 
neighbor regions of the South America, respect to the terrestrial and freshwater ecosystems: São Paulo, Brasil, Museu de Zoologia da Universidade de São Paulo, 390 p.

Smith, E.A., 1893, On the generic name to be applied to the $\mathcal{N}$ erita aurita of Müller and other allied species: Conchologist, 2, 141-142.

Sohl, N.F., 1964, Gastropods from the Coffee Sand (Upper Cretaceous) of Mississippi: United States Geological Survey, Professional Paper 331-C, 1-394.

Stilwell, J.D., 1997, Late Cretaceous Mollusca from the Chatman Islands, New Zealand: Alcheringa, 22(1), 29-85.

Stimpson, W., 1865, Researches upon the Hydrobiinae and Allied Forms: Chiefly Made upon Materials in the Museum of the Smithsonian Institution: Washington, D.C., U.S.A., Smithsonian Miscellaneous Collections, 201, 59 p.

Taylor, D.W., 1975, Early Tertiary mollusks from the Powder River Basin, WyomingMontana, and adjacent regions: United States Geological Survey, Open-File Report 75-331, 515 p.

Taylor, D.W., 1985, Evolution of freshwater drainages and molluscs in western North America, in Smiley, G.J. (ed.), Late Cenozoic history of the Pacific northwest interdisciplinary studies on the Clarkia Fossil beds of northern Idaho: San Francisco, U.S.A., Pacific Division, American Association for the Advancement of Science, 265-321.

Taylor, D.W., 2003, Introduction to Physidae (Gastropoda: Hygrophila). Biogeography, classification, morphology: Revista de Biología Tropical/ International Journal of Tropical Biology and Conservation, 51 (suppl. 1), 1-287.
Thiele, J., 1931-1935, Handbook of systematic malacology, Part I (Loricata; Gastropoda: Prosobranchia): Washington, D.G., U.S.A., Smithsonian Institution Libraries, The National Science Foundation, 625 p.

Thompson, F.G., 2011, An annotated checklist and bibliography of the land and freshwater snails of Mexico and Central America: Florida Museum of Natural History Bulletin, $1,1-299$.

Thompson, F.G., Mihalcik, E.L., 2005, Urocoptid landsnails of the genus Holospira from southern Mexico: Bulletin of the Florida Museum of Natural History, 45(3), 63-124.

Uit de Weerd, D.R., 2008, Delimitation and phylogenetics of the diverse land-snail family Urocoptidae (Gastropoda: Pulmonata) based on $28 \mathrm{~S}$ rRNA sequence data: a reunion with Cerion: Journal of Molluscan Studies, 74(4), 317-329.

Van Leeuwen, C.H.A., Huig, N., Van der Velde, G., Van Alen, T.A., Wagemaker, C.A.M., Sherman, C.D.H., Klaassen, M., Figuerola, J., 2013, How did this snail get here? Several dispersal vectors inferred for an aquatic invasive species: Freshwater Biology, 58(1), 88-99.

Vega, F.J., Perrilliat, M.C., 1989, Moluscos del Maastrichtiano de la Sierra El Antrisco, Nuevo León, México: Paleontología Mexicana, 55, 1-63.

Vega, F.J., Perrilliat, M.C., 1992, Freshwater gastropods from lower Eocene Difunta Group, northeastern Mexico: Journal of Paleontology, 66(4), 603-609.

White, C.A., 1895, The Bear River Formation and its characteristic fauna: United States Geological Survey Bulletin, 128, 1-108.

Wilke, T., Haase, M., Hershler, R., Liu, H.-P., Misof, B., Ponder, W., 2013, Pushing short DNA fragments to the limit: Phylogenetic 
relationships of 'hydrobiod' Gastropods (Caenogastropoda: Rissooidea): Molecular Phylogenetics and Evolution, 66, 715-736.

Williamson, P.G., 1981, Paleontological documentation of speciation in Cenozoic molluscs from Turkana Basin: Nature, 293, 437-443.

Wolleben, J.A., 1977, Paleontology of the Difunta Group (Upper-Cretaceous-Tertiary) in northern Mexico: Journal of Paleontology, 51(2), 373-398.
Yen, J.T.C., 1958, Systematics and distribution of Pyrgulifera Meek: Annalen des Naturhistorischen Museums in Wien, 62, 193-209.

Yen, J.T.C., 1945, Notes on a Cretaceous feeshwater gastropod from southwestern Utah: Notulae Naturae, 160, 1-3.

Zukowski, S., Walker, K.F., 2009, Freshwater snails in competition: alien Physa acuta (Physidae) and native Glyptophysa gibbosa (Planorbidae) in the River Murray, South Australia: Marine and Freshwater Research, 60(10), 999-1005. 